\title{
Environmental Leadership: Basic Requirements
}

The departure of James Watt as Secretary of the Interior Department, and the controversy surrounding his tenure as head of the oldest environmental agency in the United States, have prompted much thought on exactly what constitutes environmental leadership in today's world. While there are many requirements for such leadership, the following five surely constitute a minimum set of skills and attitudes that anyone in the position of leading a government environmental agency should possess. (It is these five following points which I suggested, in a recent New York Times editorial piece*, that the new Interior Secretary must consider.)

First, the leader of an environmental agency must be able to coordinate the efforts of his or her agency with those of other agencies-in both the public and private sectors-which are engaged in parallel and complementary missions. In the case of $\mathrm{Mr}$ Watt, he made the Interior Department an island; to some it was a utopian experiment in free market approaches to the management of natural resources, while to others it was nothing less than an environmental den of iniquity. Given the limited economic resources available for today's government environmental agencies, this approach is particularly detrimental to goals of enviornmental conservation.

Second, an agency leader must be strongly committed to research and development efforts geared towards conservation. Many technologies and techniques that will contribute substantially to resource conservation are in need of such research and development. $\mathrm{Mr}$ Watt, unfortunately, lacked any such commitment.

A third, vital requirement is commitment to strong government participation in the acquisition of wilderness and recreation areas. World-wide, human populations are growing and so are their needs for calm, clean, and uncluttered, natural sanctuaries. Some of the harshest Ed.

\footnotetext{
* Parts of 5 columns in the issue of Sunday, 16 October 1983.-
}

criticism of Mr Watt came about because of his failure to seize opportunities-now lost to development intereststo expand national parks and recreation areas through acquisition of undeveloped tracts adjacent to these areas.

Fourth, today's - and tomorrow's - environmental leader must develop progressive, balanced policies for dealing with questions of resource development on government-owned or -controlled lands. Mr Watt, feeling that much coal-rich government land was being 'wasted' by lying fallow, sought to recover the energy potential of these lands by leasing them to mining interests. He did not, however, adequately take into account potential environmental and economic costs of his actions, nor did he even think about the possibility of cultivating renewable-energy crops on these lands.

Fifth, and perhaps most fundamental of all, any director of a public environmental agency must initiate substansive and regular communication with citizens and organizations that have an interest in its activities. $\mathrm{Mr}$ Watt prided himself on being aloof from or even contemptuous of -these interest-groups. William Ruckelshaus, head of the US Environmental Protection Agency, on the contrary, has made promising efforts at establishing and maintaining strong lines of communication between his office and the environmental community.

Mr Watt's stewardship of the US Department of the Interior has provided, if nothing else, some valuable lessons on future environmental leadership -not only in the Interior Department, but also in any government agency that hopes to develop sound environmental and natural-resource management policies.

ArTHur H. PurCELL, Executive Director
Resource Policy Institute
l346 Connecticut Avenue, NW, Suite 217
Washington
DC 20036, USA.

ArTHUR H. PurCELl, Executive Director 1346 Connecticut Avenue, NW, Suite 217 DC 20036, USA

\section{'Greenhouse Effect' May Benefit the Third World}

Many climatologists agree that the world may be heading for a new dust-bowl era, but what is the cause? It is apparently the buildup of carbon dioxide $\left(\mathrm{CO}_{2}\right)$ in the atmosphere as a direct result of burning fossil fuels (especially coal and oil) and cutting down tropical forests. Atmospheric $\mathrm{CO}_{2}$ has increased from about 315 parts per million (ppm) in the 1950 s to well over $350 \mathrm{ppm}$ today. By the first half of next century, pre-industrial levels may have doubled.

This increase is likely to warm the Earth's atmosphere by an average $2^{\circ} \mathrm{C}\left(3.6^{\circ} \mathrm{F}\right)$, because $\mathrm{CO}_{2}$ 'traps' heat (infrared radiation) that would otherwise escape into space. It is thus called the 'greenhouse effect'. This could bring drought in North America, Europe, and the Soviet Union, and would be disastrous for agriculture in the temperate regions. Northerners view the prospect with alarm, but experts now realize that the 'greenhouse effect' might actually benefit the Third World. The expected warming will be distributed very unevenly-perhaps $6-8^{\circ} \mathrm{C}\left(11-14^{\circ} \mathrm{F}\right)$ at high latitudes far north and south of the Equator, and less than $1^{\circ} \mathrm{C}\left(2^{\circ} \mathrm{F}\right)$ at the Equator. Most of the world's people, especially the hungry people, live at the lower latitudes.

Climatologists' computer models indicate a slight increase in rainfall in the lower latitudes, with more water than currently evaporating from the sea and falling as rain. In general, warmer and wetter conditions can only be beneficial for such staple crops as rice, by lengthening growing-seasons and allowing two crops a year where only one can grow now. Furthermore, increased concentration of carbon dioxide may be beneficial to crops, stimulating photosynthesis so that they grow faster. So it is hard to see how the 'greenhouse effect' can be regarded as anything other than a good thing for the farmers of the Third World.

A problem may lie in the world's current reliance on food surpluses from the North, as any disruption of this system is bound to cause difficulties in the short term. If the perceived 'threat' of the 'greenhouse effect' leads to an ill-conceived search for a 'solution' for northern agriculture, this could divert resources from increasing Third World productivity and so constitute a different sort of carbon dioxide problem.

\section{JoHN R. GRIBBIN* Earthscan, 10 Percy Street London W1P ODR England, $U K$.}

* Dr Gribbin is author of a noted book, Future Worlds (Plenum Press, New York \& London: 224 pp., illustr., 1981), which 'addresses this problem in more detail'.-Ed. 